\title{
An early report of growth of an Aspergillus species on the wall of a lung cavity
}

\section{DOYLE}

\begin{abstract}
A report by Bristowe in 1854 of a vegetable fungus growing in a lung cavity and identified as an Aspergillus was almost certainly one of the earliest reports of $A$ fumigatus colonisation.
\end{abstract}

In their important review on pulmonary aspergillosis, in $1952,{ }^{1}$ Hinson and others included an extensive historical survey on the subject. A case report not contained in this survey, entitled "Vegetable fungus growing in a cavity of a lung," was published by Bristowe in 1854 in the Transactions of the Pathlogical Society of London.

At that time Bristowe was pathologist and curator of the museum at St Thomas's Hospital, London. The patient, a woman of 49, "had been labouring for 2 or 3 years under the ordinary symptoms of chronic bronchitis, and of this disease she died." The postmortem examination showed that "The bronchial tubes were highly congested and filled with mucopurulent fluid ... there was no deposit of tubercle ... in the apex [L lung] were two communicating cavities together about equal to a pidgeon's egg . . . they were empty of secretion ... on the upper surface of the septum, by which the cavities were imperfectly divided, was a soft velvety mass, occupying an area about equal to that of half a finger nail, and measuring close upon a line, or line and a half, in thickness. It was dry and powdery on the surface, and had a dullish green hue. It was firmly attached to the wall of the cavity ... Under the microscope it exhibited a distinct mycelium, and a perfectly developed fructification" (fig 1). He then elaborated on these two forms. He confessed: "I am not very conversant with the lower forms of fungi and know of none perfectly identical with this." It had "a considerable likeness," however, to fungi recovered from the respiratory tract of two separate birds (an eider duck and a snowy owl) (fig 2). These were depicted in Robin's work Végétaux Parasites (1853), having been culled from two earlier reports by Deslongchamps and by Müller and Retzius.

Address for reprint requests: Dr L Doyle, Wythenshawe Hospital, Manchester M23 9LT.

Accepted 2 November 1988

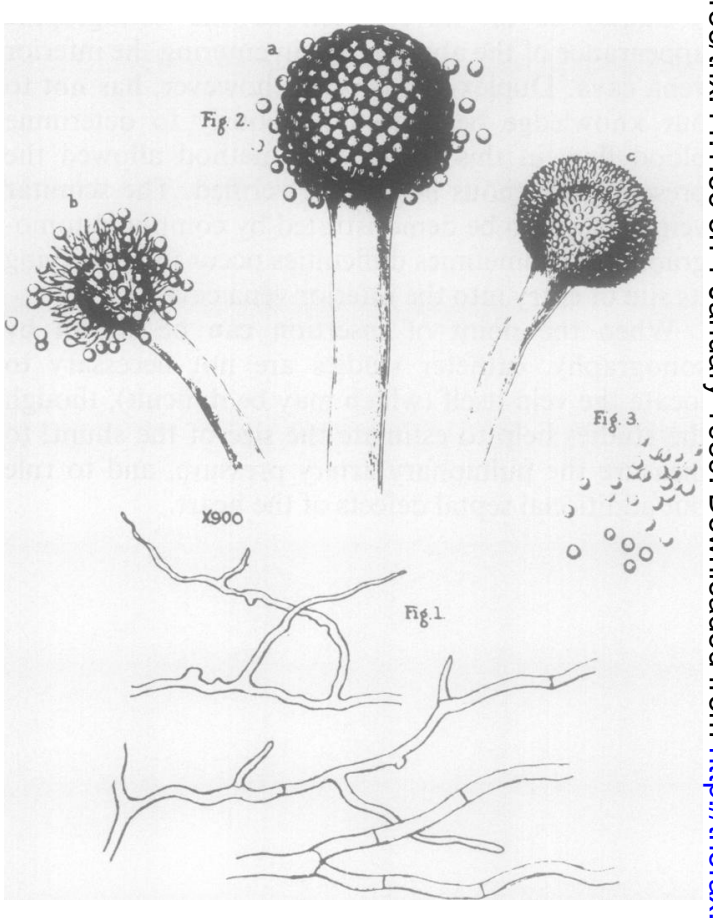

Fig 1 Illustrations from Bristowe's paper on fungus from a cavity in the lung. ${ }^{2}$ The legends to the original figures were: (1) Mycelium of fungus. (2) Fructification of the same. (a) Head covered with sporules. (b) Sporules partly separated; some are seen attached to the attenuated extremities of bottle-shaped processes. (c) Head from which sporules are completely separated, or, possibly on which they have not yet appeared. (3) Sporules. These figures are all magnified 900 diameters [the present magnification is slightly less].

Copies of Bristowe's report and of the plate and its caption were sent to the International Mycologica? Institute at Kew for comment. Dr Z Lawrence wrote "... It is very difficult to identify with certainty the species in your line drawing. It is certainly an Asper gillus and would appear to uniseriate ... the fungus had a "dullish green hue" ... A fumigatus, when firs isolated from human tissue, does display aberran? growth ... on the evidence provided it would be a safe 

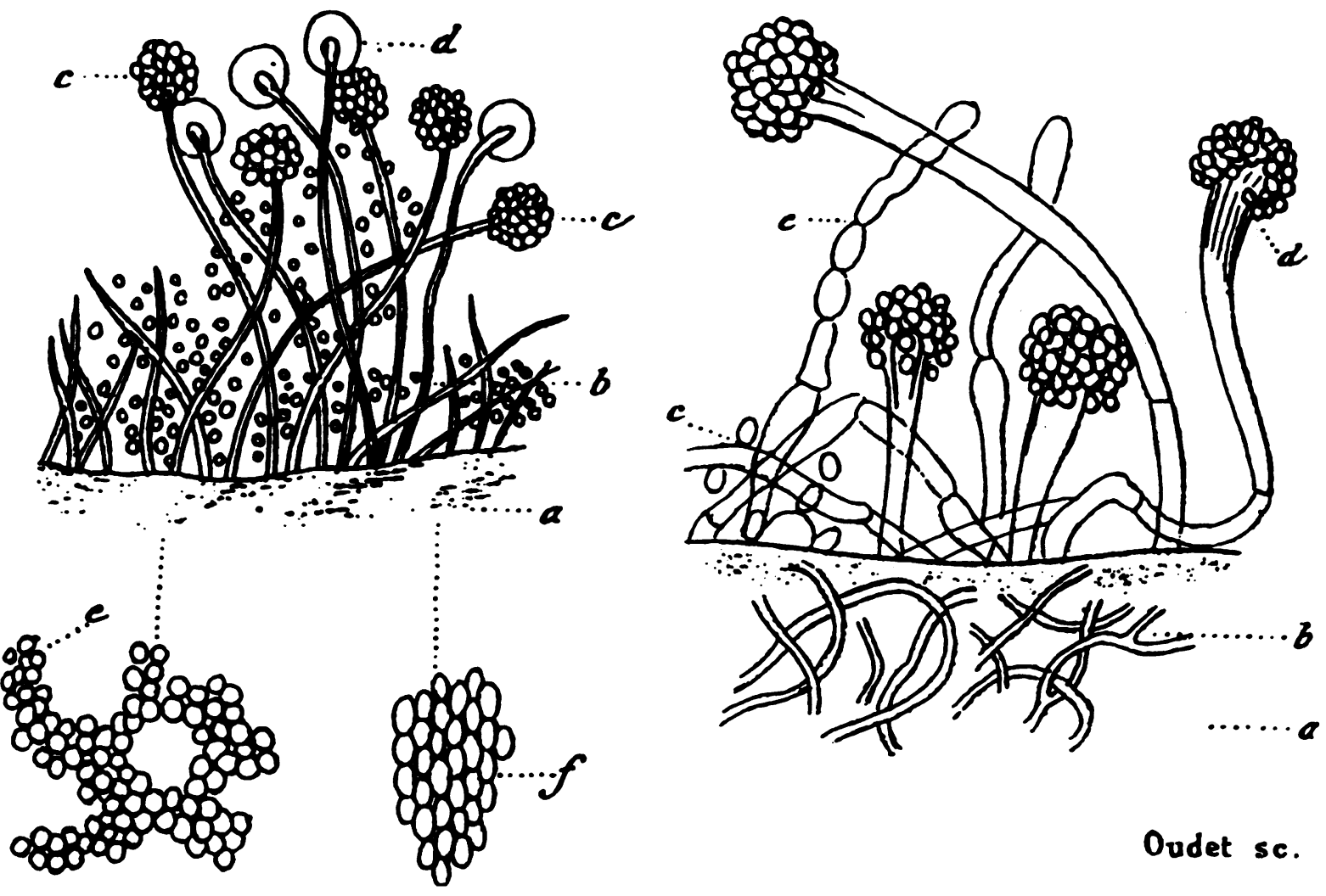

Fig 2 Funguses recovered from the respiratory tract of (a) an eider duck, (b) an owl. From Robin's book "Histoire Naturelle Des Végétaux Parasites." 3

bet to assume that it was this species ..."

In summary, Bristowe in 1854 probably recorded a growth of $A$ fumigatus on the wall of a lung cavity of undetermined origin.

I wish to acknowledge help from the John Rylands University Library, Manchester; the library of the University of Reading; Dr Z Lawrence, International Mycological Institute, Kew; and Miss Margaret Culliney.

\section{References}

1 Hinson KFW, Moon AJ, Plummer NS. Bronchopulmonary aspergillosis. Thorax 1952;7:317-33.

2 Bristowe JS. Transactions of the Pathological Society of London 1854;5:38-41.

3 Robin C. Histoire naturelle des végétaux parasites. Paris: J-B Baillière, 1853: 531-3 (with fig 4 on plate 2), 528-9 (with fig 13 on plate 2). 